\title{
EFFECT OF DIETARY PROTEIN LEVELS AND SEX ON GROWTH PERFORMANCE, FEED UTILIZATION AND BODY COMPOSITION OF NILE TILAPIA (OREOCHROMIS NILOTICUS) FRY CULTURED IN HAPS.
}

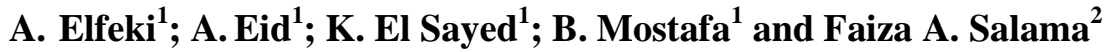 \\ ${ }^{1}$ Faculty of Agriculture- Department of Animal and Fish Resources-Suez Canal University- Ismailia- \\ Egypt. \\ ${ }^{2}$ Animal Production Research Institute. Agricultural Research Center- Giza-Egypt.
}

(Received 5/9/2017, accepted 24/10/2017)

\section{SUMMARY}

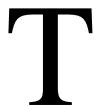

he effect of dietary protein levels $(35 \%, 40 \%$ and $45 \%)$ on growth, survival, feed utilization and body composition of mono sex and mixed sex of Nile tilapia; Oreochromis niloticus L. fry was investigated. Fish were fed frequently to satiation for 7 days a week for 56 days. Results showed that fish growth was significantly affected by protein level. The highest growth performance of fry were obtained with $45 \%$ protein diet and the poorest one was obtained with $35 \%$ protein diet in both mono and mixed sex Nile tilapia, Oreochromis niloticus fry. Mono sex tilapia were reared in hap in earthen pond showed the highest weight gain, specific growth rate, feed conversion ratio, feed efficiency and protein efficiency ratio, while mixed-sex tilapia showed the lowest weight gain, specific growth rate, feed conversion ratio, feed efficiency and protein efficiency ratio. In conclusion, it was found that $45 \%$ crude protein had the highest growth performance parameters, feed utilization and economical evaluation for mono sex Nile tilapia (O. niloticus) fry under this experimental condition.

Keywords: Nile tilapia fry, growth, protein levels, feed conversion, body composition, economical evaluation, mono sex tilapia.

\section{INTRODUCTION}

Tilapias are widely recognized as one of the most important groups of finfish for culture purposes in a wide range of freshwater culture systems, from simple waste-fed fish to intensively stocked and managed culture systems (Fitzsimmons, 2005). Attempts have also been made in some developed countries to grow them in full-strength sea water. In Egypt, the Nile tilapia (Oreochromis niloticus) is the major farmed species and constitutes over eighty percent of aquaculture production in the country and it occurs in several rivers, and in natural as well as man-made lakes (FAO, 2011). Tilapia grows and reproduces in a wide range of environmental conditions and tolerates stress induced by handling (Tsadik and Bart, 2007). However, this efficiency of reproduction in tilapia has undesirable consequences. Problems common for many Nile tilapia culture systems are the reduction of growth rates at the onset of sexual maturity and precocious and excessive reproduction, leading to various sizes of small fish production (Lèveque,2002).

The importance of monosex tilapias has been established in many commercial contexts but there are relatively few published studies comparing the growth performance of androgen treated monosex Nile tilapia with mixed-sex tilapia, under different culture system (Mair et al., 1995). Moreover, sex-specific differences in growth were significant in $O$. niloticus where males grow significantly faster, larger and more uniform in size than females (Bwanika et al., 2007). The desirability of monosex male populations of tilapia is well established for increased production potential and low management requirements (ElSayed, 2006). 


\section{Elfeki et al.}

Protein is the main constituent of the fish body thus sufficient dietary supply is needed for optimum growth. Protein is the most expensive macronutrient in fish diet (Pillay, 1990). So, the amount of protein in the diet should be just enough for fish growth where the excess protein in fish diets may be wasteful and cause diets to be unnecessarily expensive (Ahmad, 2000). Reducing feeding costs could be a key factor for successful development of aquaculture. Protein requirements for optimum growth of the fish seem to be affected by numerous factors such as temperature, salinity, fish age and size, etc. (Cowey, 1976). Most studies are confined to fry and young tilapia, although the supplementary feed is used during grow-out phase. Furthermore, understanding the protein requirement during the grow-out period is an important thing in fish culture management. Realization of the optimum protein level for cultured fish would help to reduce the costs and maximize the feed conversion efficiency (Chiu et al., 1987). Increase in yields can result from the development and adoption of new technologies and improved farming operations (Coelli, 1995). Hence, the propagation potentiality of sex-reversed tilapia under various traditional and nontraditional culture practices must be clearly documented. Therefore, the objective of this study was to assess the optimum protein level leading to optimum growth and feed utilization of mono and mixed sex of Nile tilapia (Oreochromis niloticus L) fry.

\section{MATERIALS AND METHODS}

The experiment: - The experiment was conducted at Ramses private fish farm, Sharkya Governorate, Egypt. The experiment aimed to investigate the effect of protein levels 35, 40, and 45\% diet for mono and mixed sex (O. niloticus) fry.

\section{Experimental unit:-}

Fish were stocked in 250 fry $/ \mathrm{m}^{3}$ hapa $(2 \times 5.00 \mathrm{x} 1 \mathrm{~m})$ randomly divided into six equal experimental groups (250 fry /replicate, three replicate hapas) in earthen ponds. The hapa were supplied all day with air blowers and located in earthen pond sized (acre). Water temperature was maintained at $\left(28 \pm 1{ }^{\circ} \mathrm{C}\right)$. The part of water hapa was exchanged with freshwater $10 \%$ /day.

\section{Experimental Fish:}

Four thousand and five hundred fry monosex and mixed sex of Nile tilapia (O. niloticus) with average initial body weight of $0.02 \pm 0.01 \mathrm{~g}$ were obtained from Ramses Fish Hatchery, Sharkya Governorate, Egypt. Fish were homogenous in body weights and apparently healthy. Fish were acclimated to farm conditions for 2 weeks before the experiment started.

\section{Experimental Diets:-}

Three diets were formulated from practical ingredients (Table 1) where the protein levels were 35, 40, $45 \%$ respectively and gross energy $450 \mathrm{Kcal} / 100 \mathrm{~g}$. The experimental diets were prepared by individually weighing of each component thoroughly mixing the mineral, vitamins and additives with corn or wheat bran. This mixture was added to the components together with oil. Water was added until the mixture became suitable for making fine granules. The wet mixture was passed through CBM granule machine with fin $0.2 \mathrm{~mm}$ diameter. The produced pellets were dried at room temperature then kept until experimental start. The composition and proximate analysis of the experimental diets are presented in (Table 1). The fish were hand-fed to satiation 15 times /day throughout the experimental period 56 days.

\section{Experimental Methodology}

At the beginning and at the end of experiment 5 fish sample was taken to determine chemical analysis of body composition according to AOAC, 1995. The tested diets were analyzed for crud protein (CP \%), ether extract (EE \%), crude fiber (CF \%), ash (\%) and moisture. While whole body composition of fish samples were also analyzed except crud fiber (CF \%) according to the procedures described by standard AOAC (1995). The nitrogen free-extract (NFE \%) was calculated by differences. Fish were weighed every two weeks and the average of 4 weeks was determined by UWE MJW-300 balance to the nearest $0.01 \mathrm{~g}$. All the analytical parameters were based on the dry matter (DM) contents. Feeding rates were monitored closely and adjusted accordingly upon observation of satiation point . the fish were hand fed to satiation 15 times/ day throughout the experimental period 56 days. 
Table (1). Composition and proximate analysis of experimental diets.

\begin{tabular}{lccc}
\hline \multirow{2}{*}{ Ingredient } & \multicolumn{2}{c}{ Diets (\% protein) } & \\
\cline { 2 - 3 } & 35 & 40 & 45 \\
\hline Fish meal ( 70 \%CP) & 10.00 & 10.00 & 16.00 \\
Meat and bone meal & 5.00 & 10.00 & 10.00 \\
Corn & 19.0 & 7.0 & - \\
Wheat flour & 10.00 & 11.0 & 13.0 \\
Wheat bran & 3.0 & & - \\
Soya meal ( 44 \%P) & 47.00 & 56.00 & 57.00 \\
Fish oil & 2.00 & 2.00 & 2.00 \\
Limestone & 2.0 & 2.0 & -- \\
Fish vitamin and mineral mix ${ }^{1}$ & 2.0 & 2.00 & 2.00 \\
Proximate chemical composition $(\%)$ & & & 89.4 \\
Dry matter & 89.2 & 89.4 & 45.0 \\
Crude protein & 35.0 & 40.0 & 4.0 \\
Crude fat & 3.96 & 4.0 & 9.1 \\
Ash & 8.74 & 9.1 & 41.90 \\
NFE & 52.30 & 46.90 & 464.78 \\
GE(kcal/100g) & 3
\end{tabular}

1) Each Kg vitamin \& mineral mixture premix contained :Vitamin A, 4.8 million IU; D3, 0.8 million IU; $E$, 4 g; $K$, $0.8 \mathrm{~g}$; B1, $0.4 \mathrm{~g}$; Riboflavin, $1.6 \mathrm{~g}$; B6, $0.6 \mathrm{~g}$; B12, $4 \mathrm{mg}$; Pantothenic acid, $4 \mathrm{~g}$; Nicotinic acid, $8 \mathrm{~g}$; Folic acid, $0.4 \mathrm{~g}$; Biotin, $20 \mathrm{mg}$;choline chloride $200 \mathrm{mg}$; Mn, $22 \mathrm{~g}$; Zn, $22 \mathrm{~g} ; \mathrm{Fe}, 12 \mathrm{~g}$; Cu, $4 \mathrm{~g}$; I, $0.4 \mathrm{~g}$; Selenium, $0.4 \mathrm{~g}$ and $\mathrm{Co}, 4.8 \mathrm{mg}$.

2) Nitrogen Free Extract $=100-(\%$ Protein $+\%$ Fat $+\%$ Fiber $+\%$ Ash $)$.

3) Gross Energy based on protein $(5.65 \mathrm{Kcal} / \mathrm{g})$, fat $(9.45 \mathrm{Kcal} / \mathrm{g})$ and carbohydrate $(4.11 \mathrm{Kcal} / \mathrm{g})$. According to (NRC, 2011).

\section{Feed conversion ratio: -}

The feed conversion ratio (FCR) is expressed as the proportion of dry food fed required per unit live weight gain of fish.

$$
\text { FCR }=\text { Feed intake }(\mathrm{g} / \text { fish }) / \text { wet weight gain }(\mathrm{g})
$$

Feed Intake (FI):- Amount of consumed feed per period

$$
\text { FI }=\text { Total feed intake in hapa/ Number of fish }
$$

Protein Efficiency Ratio (PER) = weight gain $(\mathrm{g}) / \mathrm{CP}$ intake $(\mathrm{g})$

Feed Efficiency $(\mathrm{FE})=$ Fed intake $(\mathrm{g})$ / wet weight gain $(\mathrm{g})$

\section{Growth performance parameters: -}

The growth performance parameters were calculated according to the following equations.

$$
\text { Weight gain }(\mathrm{WG})=\text { final weight }(\mathrm{g})-\text { initial weight }(\mathrm{g})
$$

The specific growth rate (SGR, \%/d) was calculated by the following equation.

$\mathrm{SGR}=\{$ Ln final mean body weight - Ln initial mean body weight / time intervals (days) $\} \times 100$.

Survival rate $(S R, \%)$ : -

$\mathrm{SR}(\%)=($ Number of fish survived at the end of the experiment / Number of fish stocked at the start of the experiment) $\mathrm{X} 100$

\section{Feed and protein utilization parameters:-}

Feed and protein utilization parameters are calculated according to the following equations. 


\section{Elfeki et al.}

\section{Water quality parameters: -}

Water temperature and dissolved oxygen were measured by metteler Toledo, model 128.s/No1242. Other water quality including $\mathrm{pH}$ and ammonia were measured every two days by $\mathrm{pH}$ meter (Orion model 720 A,s/no 13062) and ammonia meter by Hanna ammonia meter. The averages of water quality parameters are presented in Table (2).

\section{Economical Evaluation}

The cost of feed to produce unit biomass of fish was estimated by a simple economic analysis. The estimation was based on local retail sale market price of all the dietary ingredients at the time of the study (2016).

Cost $/ \mathrm{kg}$ diet $(\mathrm{LE})=$ Cost per $\mathrm{Kg}$ diet .

Consumed feed to produce $1 \mathrm{~kg}$ fish $(\mathrm{kg})=$ Feed intake per fish per period/ final weight per fish $(\mathrm{Kg})$

Feed cost per $\mathrm{kg}$ fresh fish $(\mathrm{LE})=$ Step $1 \mathrm{X}$ step 2

Relative $\%$ of feed cost $/ \mathrm{kg}$ fish $=$ Respective figures for step 3/ highest figure in this step

Feed cost $/ 1 \mathrm{Kg}$ gain $(\mathrm{LE})=$ Feed intake per $\mathrm{Kg}$ gain $\mathrm{X}$ step 1

Relative \% of feed cost of $\mathrm{Kg}$ gain $=$ Respective figures for step 5/ highest figure in this step

Cost of $1 \mathrm{~kg}$ ingredients used were 9.90, 11.30, and 12.75. L.E. for 35, 40 and $45 \%$ crude protein respectively for Egypt Feed Ingredients Price.

\section{Statistical analysis:}

Data was statistically analyzed by analysis of variance as one-way ANOVA using the general linear model procedure of Statistical Analysis System (SAS Institute, 1998). Differences among means were evaluated using Duncan's Multiple Range Test (Duncan, 1955).

\section{RESULTS AND DISCUSSION}

\section{Water quality}

Table (2) outlined water quality criteria of monosex and mixed sex as effected by protein levels which reared in hapa in earthen ponds. Water temperature and other water quality parameter measurements are given in Table (2). As no apparent difference in water quality parameters were found among the treatments because all hapas in the same water in earthen ponds, the data for each experiment for the whole experimental period were pooled. Water quality was found to be within the acceptable range for tilapia growth (Stickney, 1979). The water quality data for dissolved oxygen, temperature, $\mathrm{pH}$ and ammonia measured during the study period were all within the optimum range for rearing $O$. niloticus (Xu et al., 2005; Azaza et al., 2008).

Table (2). Average physico-chemical parameters of water quality throughout experimental period 56 days (Means \pm SE).

\begin{tabular}{lcccc}
\hline Parameter & Temperature & Dissolved Oxygen & Ammonia & $\mathrm{pH}$ \\
\hline $\begin{array}{l}\text { Measurement } \\
\text { range }\end{array}$ & $28 \pm 1^{\circ} \mathrm{C}$ & $5.7 \pm 0.5 \mathrm{mg} / 1$ & $0.007-0.0028 \mathrm{mg} / 1$ & $7.7 \pm 0.7$ \\
\hline
\end{tabular}

\section{Growth performance and feed utilization}

Table (3) presents the final results for the effect of protein levels on growth performance, feed utilization and survival rate for mono and mixed sex of Nile tilapia fry. The highest growth performance parameters (body weight, body weight gain, specific growth rate) were recorded in group for monsex fry fed on diet contains $45 \%$ crude protein. The lowest growth performance parameters were recorded for group of mixed sex Nile tilapia fry fed the diet contains $35 \%$ crude protein. The highest feed utilization 
parameters (PER and feed efficiency ratio) were recorded in group of mono sex fry fed diet containing $45 \%$ crude protein and the lowest group of mixed sex fry fed on diet contains $35 \%$ crude protein. The favorite FCR was recorded in monosex fry fed diet containing $45 \%$ crude protein and the worst FCR for group of mixed sex fry fed on $35 \%$ crude protein.

The highest averages of final body weight, weight was found in monosex followed by mixed sex groups (Table 3). Increase in individual growth of Nile tilapia during monosex culture was observed in different studies (Mair et al., 1995; Dan and Little, 2000; Little et al., 2003). Faster growth of monosex tilapia has been related to the lack of energy expenditure in egg production and mouth brooding by females and lower energy expenditure on courtship by males (Dan and Little, 2000; Tran-Duy et al., 2008).

Mono sex fry gained the highest final body weight and this can be attributed to the anabolic effect of hormone to induce sex reversal in farmed tilapias. In this respect, some studies reported that the anabolic effect of hormone showed an increase in individual growth of tilapia (Mair et al., 1995 and Dan and Little, 2000). Other studies reported that the higher mean weights could be attributed to the improvement of food conversion efficiency of sex-reversed fry of Oreochromis niloticus (Dang et al., 2013). Increase in individual growth of Nile tilapia during monosex culture was observed in different studies (Dan and Little, 2000; Little et al., 2003). Al Hafedh (1999) found that, SGR of Nile tilapia was significantly increased as diet protein level increased from 25-45\% (with increment of 5\%). Also, Ogunji and Wirth (2000) with the same fish specie found that, SGR increased with increasing dietary protein level from 7.3 to $44.24 \%$.

Feed intake increased significantly with increasing dietary protein level only $(\mathrm{P}<0.01)$, in agreement with Khattab et al., (2000). Generally FI was significantly lower $(\mathrm{P}<0.05)$ in monosex than mixed sex (Table 3). The obtained results for male monosex fish means that these fish used less feed to gain more weight when compared with the mixed sex fry (Table 3). These results are in close agreement with Hossain et al., (2005) who found FCR of 1.58 and 1.64 for male monosex and mixed sex $O$. niloticus, respectively, when fed on formulated diet. Siddik et al. (2014) also reported a FCR of 1.71 and 1.78 for male monosex and mixed sex, respectively. Al Hafedh (1999) came to the same results that FCR of Nile tilapia was improved with increasing dietary protein level.

As described in Table (3), averages PER were significantly $\mathrm{P}<0.05$ ) increased with increasing protein levels in monosex fry, and were found to be negatively correlated with dietary protein level. Dabrowski (1979) found that the relationship between dietary protein and PER differs from species to species. Jauncey (1982) and De Silva et al., (1989) reported that FCR and PER decreasing with increasing dietary protein content. Siddiqui et al., (1988) found that, PER decreased with increasing diet protein level from 20 to $50 \%$ for Nile tilapia. Also, El-Ebiary (1994) found that, increasing dietary protein level up to $35 \%$ and feeding rate up to $4 \%$ decreased the values of nutrients (protein and energy) utilization in Nile tilapia and its hybrid. In many fish including tilapia, it has been reported that the protein requirement of the fish decreased with increasing size (El-Saidy and Gaber 2005).There was a general decrease in FCR and increase in PER for monosex fish than the mixed-sex ones. Such observation may be related to the fact that FCR decreases while PER increases with increased feeding rate (Pechsiri and Yakupitiyage, 2005).

In general, survival rate was high for all experimental groups (Table 3). There were no significant differences $(\mathrm{P}>0.05)$ between and within experimental groups of mono and mixedsex of Nile tilapia $(O$. niloticus) fry fed the experimental diets. The survival rates were $96,96,98,96,96$ and $96 \%$ for T1, T2, T3, T4, T5 and T6, respectively. El-Sayed and Teshima (1992) demonstrated that $O$. niloticus fry require $45 \%$ protein and $400 \mathrm{kcal} / 100 \mathrm{~g}$ for maximum growth when reared under laboratory conditions, in agreement with the present study.

These variations appear to be the result of different experimental conditions, which include fish species, size and age of fish, stocking density, protein quality, hygiene and environmental conditions, particularly temperature, which has been found to influence dietary protein requirement in tilapia (Jauncey and Ross, 1982) and in some other fish species (Wilson, 1989). The ratio of protein to energy in the diet has also been reported to influence the growth and feed conversion efficiency in $O$. niloticus fry (El-Sayed and Teshima, 1992).

\section{Effect of protein level on body composition}

Results of body composition of each mono and mixed sex Nile tilapia fry fed diets containing 35, 40 and $45 \%$ crude protein are summarized in Table (4). Moisture, protein and lipid contents in whole fish 


\section{Elfeki et al.}

body were affected by fish sex and dietary protein level. The interaction of both factors affects body chemical analysis. Generally, the moisture content in monosex tilapia was significantly lower $(\mathrm{P}<0.05)$ than the mixed-sex fish. But, Killian and Kohler (1991) recorded significant increase in moisture content in $17 \alpha$-Metheytestestron treated Coho salmon. The body protein content was direct proportionally affected by protein levels $(\mathrm{P}<0.05)$. Fish fed $35 \%$ protein diet had lower content of protein and higher content of lipid than fish fed $40 \%$ or $45 \%$ protein diets. These results are similar to that obtained by Wee and Tuan (1988) and Al Hafedh (1999). Ash content in whole fish body was unaffected by dietary protein levels at all both fish sex of fish fry. The body protein percentage on a wet weight basis is mainly affected by the body weight in salmonids (Shearer, 1994). Similar observations have been noticed in Nile tilapia also where body protein content increases with increasing wet weight (Abdelghany and Mohammed, 2002). This explains the higher protein content of the monosex fish than the corresponding mixed-sex fish. Ash content was unaffected by dietary protein level but affected by fish size. Khattab et al., (2000) reported that ash content was unaffected by protein level in Nile tilapia collected from Abbassa fishponds.

Table (3). Effect of protein levels on growth performance, feed utilization and survival rate of mono and mixed sex Nile tilapia $(O$. niloticus) fry throughout the experimental period (56 days).

\begin{tabular}{|c|c|c|c|c|c|c|}
\hline \multirow[t]{2}{*}{ Parameter } & \multicolumn{3}{|c|}{ Mono sex } & \multicolumn{3}{|c|}{ Mixed sex } \\
\hline & T1 (35) & T2 (40) & T3 (45) & T4 (35) & T5(40) & T6 (45) \\
\hline \multirow[t]{2}{*}{ Average Initial weight $(\mathrm{g}$} & 0.2 & 0.2 & 0.2 & 0.2 & 0.2 & 0.2 \\
\hline & \pm 0.01 & \pm 0.01 & \pm 0.01 & \pm 0.01 & \pm 0.14 & \pm 0.01 \\
\hline \multirow[t]{2}{*}{ Average Final weight (g). } & 4.80 & 5.80 & 10.20 & 4.60 & 5.10 & 9.60 \\
\hline & $\pm 0.10^{\mathrm{e}}$ & $\pm 0.10^{\mathrm{c}}$ & $\pm 0.10^{\mathrm{a}}$ & $\pm 0.10^{\mathrm{e}}$ & $\pm 0.10^{\mathrm{d}}$ & $\pm 0.10^{\mathrm{b}}$ \\
\hline \multirow{2}{*}{ Average Weight gain $(\mathrm{g})$} & 4.60 & 5.60 & 10.00 & 4.40 & 4.90 & 9.40 \\
\hline & $\pm 0.40^{\mathrm{e}}$ & $\pm 0.60^{\mathrm{c}}$ & $\pm 0.40^{\mathrm{a}}$ & $\pm 0.20^{\mathrm{e}}$ & $\pm 0.40^{\mathrm{d}}$ & $\pm 0.20^{\mathrm{b}}$ \\
\hline \multirow{2}{*}{$\begin{array}{l}\text { Specific } \\
(\% / \text { day })\end{array}$} & 5.68 & 6.01 & 7.02 & 5.60 & 5.78 & 6.91 \\
\hline & $\pm 0.10^{\mathrm{e}}$ & $\pm 0.10^{\mathrm{c}}$ & $\pm 0.10^{\mathrm{a}}$ & $\pm 0.10^{\mathrm{e}}$ & $\pm 0.10^{\mathrm{d}}$ & $\pm 0.10^{\mathrm{b}}$ \\
\hline \multirow[t]{2}{*}{ Feed Intake (FI) (g) } & 7.30 & 7.70 & 10.50 & 9.80 & 8.70 & 11.50 \\
\hline & $\pm 1.0 \mathrm{f}$ & $\pm 0.10^{\mathrm{d}}$ & $\pm 0.10^{\mathrm{b}}$ & $\pm 0.10^{\mathrm{e}}$ & $\pm 0.10^{\mathrm{c}}$ & $\pm 0.10^{\mathrm{a}}$ \\
\hline \multirow[t]{2}{*}{ Feed Conversion Ratio $(\mathrm{FCR})(\mathrm{g} / \mathrm{g})$} & 1.59 & 1.37 & 1.05 & 2.23 & 1.77 & $1.22 \pm$ \\
\hline & $\pm 0.10^{\mathrm{e}}$ & $\pm 0.10^{\mathrm{e}}$ & $\pm 0.10^{\mathrm{e}}$ & $\pm 0.10^{\mathrm{e}}$ & $\pm 0.10^{\mathrm{e}}$ & $0.10^{\mathrm{e}}$ \\
\hline \multirow{2}{*}{ Feed Efficiency $(\mathrm{FE})(\mathrm{g} / \mathrm{g})$} & 0.63 & 0.73 & $0.95 \pm$ & 0.45 & 0.56 & 0.82 \\
\hline & $\pm 0.10^{\mathrm{d}}$ & $\pm 0.10^{\mathrm{c}}$ & $0.10^{\mathrm{a}}$ & $\pm 0.10^{\mathrm{e}}$ & $\pm 0.10^{\mathrm{e}}$ & $\pm 0.10^{\mathrm{b}}$ \\
\hline \multirow[t]{2}{*}{ protein efficiency Ratio (PER) } & 8.36 & 10.37 & 21.7 & 5.64 & 7.00 & 17.40 \\
\hline & $\pm 0.10^{\mathrm{b}}$ & $\pm 0.10^{\mathrm{b}}$ & $\pm 0.10^{\mathrm{a}}$ & $\pm 0.10^{\mathrm{d}}$ & $\pm 0.10^{\mathrm{c}}$ & $\pm 0.10^{\mathrm{b}}$ \\
\hline \multirow{2}{*}{ Survival rate $\%$} & 96.00 & 96.00 & 98.00 & 96.00 & 96.00 & 96.00 \\
\hline & $\pm 0.10^{\backslash}$ & \pm 0.10 & \pm 0.10 & \pm 0.10 & \pm 0.10 & \pm 0.10 \\
\hline
\end{tabular}

$*$ Means in the same row having the same superscript letter are not significantly different $(P>0.05)$.

Table (4). Effect of protein levels on body composition ((\% on wet basis Mean \pm SE) of monosex and mixed sex of Nile tilapia $(O$. niloticus) fry throughout the experimental period (56 days).

\begin{tabular}{lcccccc}
\hline Content & \multicolumn{3}{c}{ Mono sex } & \multicolumn{3}{c}{ Mixed sex } \\
\cline { 2 - 7 } & T1(35\%) & T2(40\%) & T3(45\%) & T4(35\%) & T5(40\%) & T6(45\%) \\
\hline Moisture & $71.6 \pm 0.14^{\mathrm{b}}$ & $71.0 \pm 0.56^{\mathrm{b}}$ & $70.46 \pm 0.04^{\mathrm{c}}$ & $72.30 \pm 1.5^{\mathrm{a}}$ & $72.20 \pm 0.9^{\mathrm{a}}$ & $71.15 \pm 1.4^{\mathrm{b}}$ \\
Crude protein & $15.44 \pm 0.10^{\mathrm{d}}$ & $16.20 \pm 0.12^{\mathrm{c}}$ & $17.10 \pm 0.14^{\mathrm{a}}$ & $14.40 \pm 0.14 \mathrm{e}$ & $15.00 \pm 0.14 \mathrm{~d}$ & $16.40 \pm 0.14 \mathrm{~b}$ \\
Crude Lipid & $6.86 \pm 0.15^{\mathrm{a}}$ & $6.60 \pm 0.27^{\mathrm{b}}$ & $6.24 \pm 0.21^{\mathrm{c}}$ & $7.20 \pm 0.15^{\mathrm{a}}$ & $6.60 \pm 0.27^{\mathrm{b}}$ & $6.25 \pm 0.21^{\mathrm{c}}$ \\
Ash & $6.10 \pm 0.15$ & $6.20 . \pm 0.15$ & $6.20 \pm 0.15$ & $6.10 \pm 0.15$ & $6.20 . \pm 0.15$ & $6.20 \pm 0.15$ \\
\hline
\end{tabular}

\footnotetext{
* Means in the same row having the same superscript letter are not significantly different $(P>0.05)$.
} 


\section{Economical evaluation}

The cost of all topics involved in the present investigation were constant, therefore recalculation of the economical evaluation of the tested diets based on the cost of feed, cost of one $\mathrm{Kg}$ weight gain and the relative of feed cost for the biggest group comparable to the other fish groups (Table 5). Feed costs (L.E) were the highest for T3 and T6 (45\% crude protein) and generally decreased with decreasing crude protein levels in the diets (Table 5). The lowest feed cost $/ 1 \mathrm{Kg}$ gain $(13.39 \mathrm{LE})$ in $\mathrm{T} 3$ and relative $\%$ of feed cost of $\mathrm{Kg}$ gain $(60.64 \%)$ and the highest feed cost $/ \mathrm{kg}$ gain was recorded in T5 (22.08L.E) in and relative $\%$ of feed cost of $\mathrm{Kg}$ gain $(100 \%)$. The reduction of feed cost $/ \mathrm{Kg}$ was easily observed for the feed cost per $\mathrm{Kg}$ weight gain which decreased in mono sex than mixed sex. These results indicate that T3 ( $45 \%$ crude protein) for mono sex Nile tilapia (O. niloticus) fry is the best in terms of economic analysis as noted in (Table 5).

\section{CONCLUSION}

It was found that $45 \%$ crude protein had the highest growth performance parameters, feed utilization and economic analysis for monosex Nile tilapia (O. niloticus) fry under this experimental condition.

Table (5). Effect of protein levels economical evaluation of mono and mixed sex of Nile tilapia ( $O$. niloticus) fry throughout the experimental period (56 days).

\begin{tabular}{lcccccc}
\hline & \multicolumn{3}{c}{ Mono-Sex } & \multicolumn{3}{c}{ Mixed Sex } \\
\cline { 2 - 7 } Parameter & T1 (35\%) & T2 (40\%) & T3 (45\%) & T4 (35\%) & T5(40\%) & T6 (45\%) \\
\hline Cost of Kg diet & 9.9 & 11.3 & 12.75 & 9.9 & 11.3 & 12.75 \\
Feed intake (FI) (g) & 7.30 & 7.70 & 10.50 & 9.80 & 8.70 & 11.50 \\
Feed cost/ kg fish & 72.27 & 87.01 & 133.87 & 97.02 & 98.31 & 146.62 \\
Relative to feed cost \% & 49.00 & 59.00 & 91.00 & 66.00 & 67.00 & 100 \\
(FCR)(g/g) & 1.59 & 1.37 & 1.05 & 2.23 & 1.77 & 1.22 \\
Feed cost/1Kg gain(L.E) & 15.74 & 15.48 & 13.39 & 22.07 & 22.08 & 15.55 \\
Relative \% of feed cost/ & 71.28 & 70.10 & 60.64 & 89.25 & 100 & 70.42 \\
kg gain fish & & & & & & \\
\hline
\end{tabular}

\section{REFERENCES}

A. O. A. C. (1995). Association of official analytical chemists, official methods of analysis. 16th edition, AOAC, Arlington, VA. 1832.

Abdelghany, A.E. and H.A., Mohammed (2002). Effects of feeding rates on growth and production of Nile tilapia, common carp and silver carp polycultured in fertilized ponds. Aquaculture Research, 33: 415-423.

Ahmad, M.H. (2000). Improve productive performance in fish. Ph.D. Dissertation, Animal Prod. Department, Faculty of Agriculture, Zagazig University.

Al Hafedh, Y.S. (1999). Effects of dietary protein on growth and body composition of Nile tilapia, Oreochromis niloticus L. Aquaculture Research, 30(5): 385-393.

Azaza, M. S.; M. N., Dhraief and M. M. Kraiem (2008). Effects of water temperature on growth and sex ratio of juvenile Nile tilapia Oreochromis niloticus (Linnaeus 1758) reared in geothermal waters in Southern Tunisia. Journal of Thermal Biology, 33, 98 - 105. 


\section{Elfeki et al.}

Bwanika, G.N.; D.J. Murie; and L.J. Chapman (2007). Comparative age and growth of Nile tilapia (Oreochromis niloticus L.) in lakes Nabugabo and Wamala, Uganda. Hydrobiologia, 589: 287-301.

Chiu, Y.N.; N.S. Sumagaysay; and M.S. Sastrillo (1987). Effect of feeding frequency and feeding rate on the growth and feed efficiency of milkfish (Chanos chanos). Asian Fish. Sci., 1: 27-31.

Coelli, T.J. (1995). Recent development in frontier modeling and efficiency measurement. Australian Journal of Agricultural Economics, 39: 215-245.

Cowey, C. (1976). Use of synthetic diets and bio-chemical criteria in assessment of nutrients requirements of fish. J. Fish Res. Bd. Can., 33: 1040-1045.

Dabrowski, K. (1979). Feeding requirements of fish with particular attention to common carp. A review. Polish Archive for Hydrobiology, 26, 135- 158.

Dagne, A.; F. Degefu; and A. Lakew (2013). Comparative Growth Performance of Mono-Sex and MixedSex Nile Tilapia (Oreochromis niloticus L.) in Pond Culture System at Sebeta, Ethiopian. International Journal of Aquaculture, 3, 30-34.

Dan, N.C. and D.C. Little (2000). The culture performance of monosex and mixed-sex new-season and overwintered fry in three strains of Nile tilapia (Oreochromis niloticus) in Northern Vietnam. Aquaculture, 184: 221-231.

De Silva, S.S.; R.M. Gunasekera and D. Atapattu (1989). The dietary protein requirements of young tilapia and an evaluation of the least cost of dietary protein levels. Aquaculture, 80, 271284.

Duncan, D.B. (1955). Multiple range and multiple (F) test. Biometrics, 11: 1- 42.

El-Ebiary, E.H.A. (1994). Studies on fish production: Relationship between nutrition and reproduction of tilapia sp. Ph.D. Thesis, Fac. of Agric., Alex. University.

El-Saidy, D.M.S.D.; and M.M.A. Gaber (2005). Effect of Dietary Protein Levels and Feeding Rates on Growth Performance, Production Traits and Body Composition of Nile tilapia, Oreochromis niloticus (L.) Cultured in Concrete Tanks. Aquaculture Research, 36, 163-171.

El-Sayed, A-F.M. (2006). Tilapia Culture. CABI Publishing, CAB Internnational, Wallingford, Oxfordshire, UK, $277 \mathrm{pp}$

El-Sayed, A.-F.M.; and S. Teshima (1992). Protein and energy requirement of Nile tilapia, Oreochromis niloticus, fry. Aquaculture, 103: 55-63.

FAO (2011). Food Agriculture Organization, National Aquaculture Sector Overview: Ghana. Technical report, Rome, Italy. Fisheries Act 625. 2002.

Fitzsimmons, K. (2005). Tilapia culture. In: Kelly, A. M., Silverstein, J. (eds), Aquaculture in the $21^{\text {st }}$. Century: American Fisheries Society; Symposium 46, Bethesda, Maryland, p. 563-590.

Hossain, M.A.; A.A. Hossain and N. Sultana (2005). Overwintering growth of normal and monosex GIFT Tilapia, Oreochromis niloticus in Bangladesh fed on formulated diet. Journal of Aquaculture in the Tropics, 20, $271-286$.

Jauncey, A. (1982). The effect of varying dietary protein level on the growth, food conversion, protein utilization and body composition of juvenile tilapias (Sarotherodon mossambicus). Aquaculture, 27, 43- 54. 
Jauncey, K. and B. Ross (1982). A Guide to Tilapia Feeds and Feeding. University of Stirling,

Scotland. $111 \mathrm{pp}$.

Khattab, Y.A.E.; M.H. Ahmad; A.M.E. Shalaby; and M. Abdel-Tawwab, (2000). Response of Nile tilapia (Oreochromis niloticus L.) from different locations to different dietary protein levels. Egypt. J. Aquat. Biol. and Fish., 4(4): 295-311.

Killian, H.S. and C.C. Kohler (1991). Influence of $17 \alpha$ - methyltestosterone on Red Tilapia under two thermal regime. Journal of World Aquaculture Society, 22(2): 83-94.

Lèveque, C. (2002). Out of Africa: the success story of tilapias. Environmental Biology of Fishes, 64: 461- 464

Little, D. C.; R. C. Bhujel and T. A. Pham (2003). Advanced nursing of mixed-sex and mono-sex tilapia (Oreochromis niloticus) fry, and its impact on subsequent growth in fertilized ponds. Aquaculture, 221, 265-276.

Mair, G.C.; J.S. Abucay; J.A. Beardmore and D.O.F. Skibinski, (1995). Growth Performance Trials of Genetically Male Tilapia (G17a-MT) Derived from YY-Males in Oreochromis niloticus L.: On Station Compositions with Mixed Sex and Sex Reversed Male Populations. Aquaculture, 137, 313-332.

NRC (National Research Council). (2011). Nutrient requirements of fish. Committee on Animal Nutrition Board on Agriculture. National Academy Press, Washington D. C, USA. p.114.

Ogunji, J. O. and M. Wirth (2000). Effect of dietary protein content on growth, food conversion and body composition of tilapia Oreochromis niloticus fingerlings fed fish meal diet. J. Aquac. Trop. 15(4) :381404.

Pechsiri, J. and A. Yakupitiyage (2005). A comparative study of growth and feed utilization efficiency of sex reversed diploid and triploid Nile tilapia, Oreochromis niloticus L. Aquaculture Research, 36: 4551.

Pillay, T.V.R. (1990). Aquaculture: Principles and Practices. Fishing News Book. Blackwell Scientific Publications, Ltd., Oxford, UK. pp. 575.

SAS (1998). SAS Statistical Software, version 8. SAS Institute, Cary, NC.

Shearer, K.D. (1994). Factors affecting the proximate composition of cultured fishes with emphasis on salmonids. Aquaculture, 119: 63-88.

Siddik, M. A. B.; A. Nahar; F. Ahamed and M. Y. Hossain (2014). Over-wintering growth performance of mixed-sex and mono-sex Nile tilapia Oreochromis niloticus in Northeastern Bangladesh. Croatian Journal of Fisheries, 72, $70-76$.

Siddiqui, A.Q.; M.S. Howlander; and A.A. Adam (1988). Effects of dietary protein levels on growth, diet conversion and protein utilization in fry and young Nile tilapia, Oreochromis niloticus. Aquaculture,70: 63-70.

Stickney, R.R. (1979). Principles of Warm water Aquaculture. Wiley Interscience, New York, USA.

Tran-Duy, A.; J.W. Schrama; A.A. Van Dam; and J.A.J. Verreth (2008). Effects of oxygen concentration and body weight on maximum feed intake, growth and hematological parameters of Nile tilapa (Oreochromis niloticus). Aquculture, 275(1-3):152-162.

Tsadik, G. G. and A. N. Bart (2007). Effects of feeding, stocking density and water-flow rate on fecundity, spawning frequency and egg quality of Nile tilapia, Oreochromis niloticus (L.). Aquaculture, 272, 380-388. 


\section{Elfeki et al.}

Wee, K.L.; and N.A. Tuan (1988). Effects of dietary protein level on growth and reproduction in Nile tilapia (Oreochromis niloticus), pp. 401-410. In R. S. V. Pullin, T. Bhukaswan, K. Tonguthai and J. L. Maclean (eds.).

Wilson, R.P. (1989). Protein and amino acid requirements of fishes. In: Progress in Fish Nutrition (ed. S.Shiau), pp. 51- 76. National Taiwan Ocean University, Keelung, Taiwan.

Xu, J. Y.; X. W. Miao; Y. Lu and S. R. Cui (2005). Behavioral response of tilapia (Oreochromis niloticus) to acute ammonia stress monitored by computer vision. Journal of Zhejiang University Science, 6, 812-816.

تأثثير مستويات البروتين والجنس على أداء النمو والاستفادة من الغذاء وتركيب الجسم ليرقات البلطي النيلي

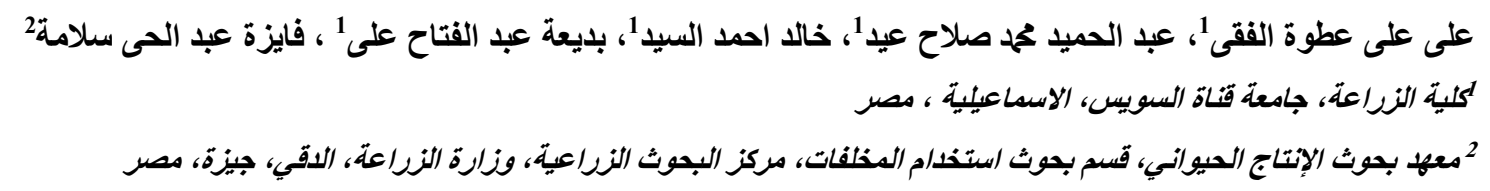

تأثير مستوى بروتين العليقة (35،40،40\%) على النمو وكفاءة الاستفادة من الغذاء وتركيب الجسم ليرقات البلطي النيلي وحيد

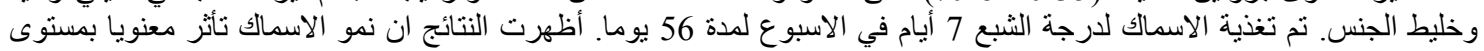

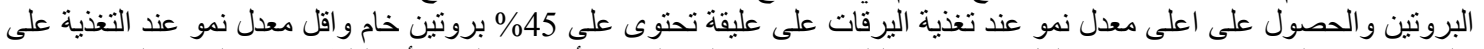

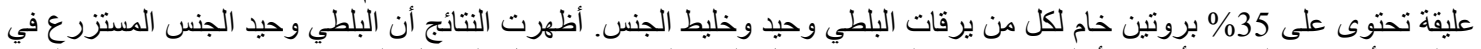

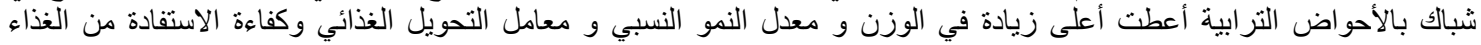

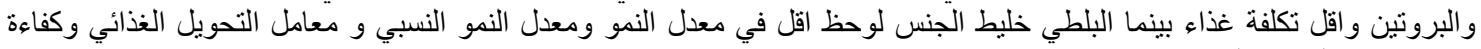

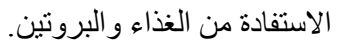

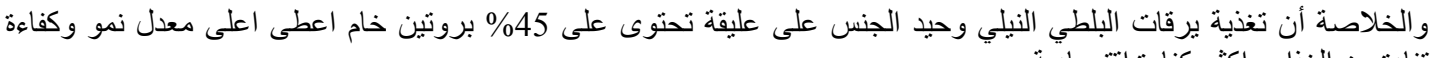
الاستفادة من الغذاء واكثر كفاءة اقتصادية 